\title{
Penerapan Buffer Analysis dalam bidang Teknik Sipil dan Lingkungan
}

\author{
Vita Fajriani Ridwan) \\ Jurusan Teknik Sipil Politeknik Negeri Ujung Pandang -Makassar
}

Korespondensi : vitaridwan@gmail.com

\begin{abstract}
ABSTRAK
Perkembangan teknologi GIS menyediakan konsep, alat, dan analisis yang mendukung kebutuhan teknik sipil dan lingkungan. Tulisan ini membahas secara singkat konsep buffer analysis/multiple ring buffer analysis pada platform GIS dalam aplikasi teknik sipil dan lingkungan. Tulisan ini menjelaskan penelitian-penelitian sebelumnya yang menerapkan buffer analysis/multiple ring buffer analysis. Buffer analysis/multiple ring buffer analysis digunakan untuk mengetahui area layanan (halte bus, shelter untuk bencana), yang umum digunakan dalam teknik sipil; dan untuk memahami area dampak (perletakan TPA, kebisingan), yang umum digunakan dalam bidang teknik sipil dan lingkungan. Tulisan ini menyebutkan keterbatasan buffer analysis/multiple ring buffer analysis yang hanya berfokus pada variabel jarak.
\end{abstract}

Kata Kunci : Jembatan rangka baja, gaya dalam, deformasi, super structur

\section{PENDAHULUAN}

Teknik sipil merupakan bidang ilmu yang mencakup bagaimana mengembangkan infrastruktur secara berkesinambungan, dimulai dari ide, design, pembiayaan hingga pelaksanaan. Sementara teknik lingkungan fokus kepada masalah lingkungan, umumnya menyangkut dampak lingkungan (environmental impact). Dalam prakteknya teknik sipil dan lingkungan berhubungan dan berkesinambungan dan tak jarang saling beririsan, seperti pada proyek pengembangan system penyediaan air minum, teknik sipil fokus pada desain dan bangunan, sementara teknik lingkungan berkutat pada system lingkungannya seperti masalah pencemaran air.

Ruang lingkup pekerjaan teknik sipil dan lingkungan tergolong besar, dengan cakupan data yang besar dari berbagai sumber dengan salah satu unsur spasial di dalamnya. Dalam pengolahan data yang besar dengan sumber yang beragam, manajemen data menjadi sebuah keniscayaan.
GIS (Geographic Information System) atau SIG (Sistem Informasi Geografi) adalah salah satu teknologi informasi yang berbasis keruangan yang menyediakan alat bantu untuk membuat, mengatur, menganalisa, hingga menampilkan dan merepresentasikan data. Dengan konsep, tool, dan system analisis yang ada, dalam bidang teknik sipil dan lingkungan, GIS memudahkan untuk mengatur dan berbagi data serta menampilkan data yang kompleks dalam bentuk presentasi yang lebih mudah dipahami dalam bentuk gambar. Lebih lanjut, teknologi GIS dapat bekerja dengan beragam format data yang umumnya digunakan dalam bidang sipil dan lingkungan juga dapat mengintegrasikan data-data tersebut dengan peta, gambar satelit, termasuk gambar CAD(Esri, 2012). 


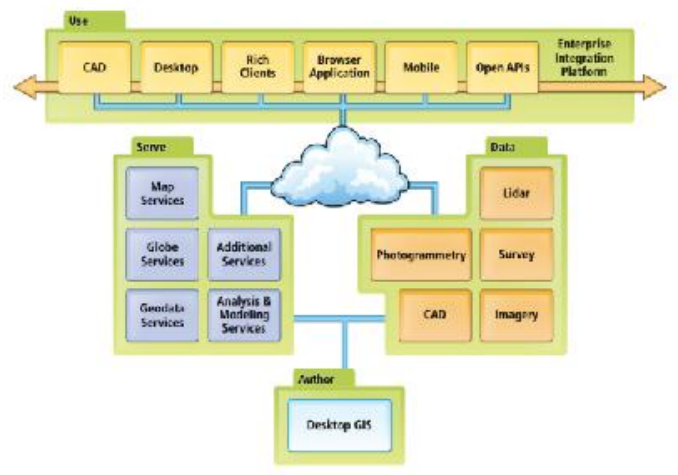

Gambar 1. Workflow pengerjaan data yang berhubungan dengan teknik sipil dan lingkungan dalam lingkungan GIS(Esri, 2012)

Menurut Mitchell,sama halnya dengan teknik overlay,buffer analysis termasuk dalam kelompok analisis GIS yang bersifat tradisional (1999). Dalam dunia pertahanan keamanan dan bencana, teknik ini sering digunakan sejak dahulu untuk mengetahui batas pergerakan criminal, batas pergerakan orang yang hilang atau tersesat, tentu saja dengan variable jarak yang berbeda untuk setiap kasus.

Sistem ini secara umum membagi dua zona wilayah; wilayah dalam cakupan buffer dan wilayah di luar buffer. Biasanya cakupan buffer berupa jarak terhadap satu feature (baik itu berupa point/titik, line/garis, hinggapolygon/poligon). Wilayah dalam cakupan buffer bisa hanya satu ataupun lebih. Untuk yang lebih dari satu, penerapannya dengan menggunakan multiple ring buffer analysis.

Teknik analisis ini adalah bagian dari proximity analisis. Fungsi proximity analisis secara umum untuk mengetahui jarak sesuatu dengan sesuatu lainnya, seperti; seberapa dekat sumber air ke pemukiman hingga untuk mengetahui keberadaan pemukiman dalam rentang 1000 meter dari bandara. Teknik ini dibedakan atas 2 kelompok berdasarkan tipe data yang diinput, apakah dalam bentuk feature ataukah dalam bentuk raster. Buffer analysis termasuk dalam kelompok pertama yaitu kelompok feature ("Proximity analysis," n.d.).

Spatial analysis merupakan bagian yang penting dari metode analisis perancangan (Wang \& vom Hofe, 2007). Bersama dengan overlay, network analysis, buffer analysismerupakan bagian analisis ini baik di platform ArcGIS maupun QGIS. Bedanya, jika di ArcGIS, buffer analysis merupakan bagian dari proximity analysis, di QGIS teknik analisis ini merupakan bagian dari analisis spasial vector.

Dalam proses analisisnya, input dari analisis ini terdiri dari tiga jenis feature utama, yaitu:

1. Point. Feature ini dapat berupa titik lokasi untuk bus stop, shelter, hingga bangunan irigasi

2. Line. Feature ini secara umum adalah kelompok jaringan (jalan, sungai, jaringan irigasi hingga jalur kereta api)

3. Polygon. Feature ini berupa area kawasan, baik pemukiman, perkantoran, hingga public space

\section{Metode penelitian}

Pada studi ini dikaji pengaplikasian buffer analysis dalam ranah teknik sipil dan lingkungan dengan menggunakan teknik literature review.

\section{Analisis}

Tabel 1. Penelitian dengan buffer analysis dalam bidang teknik sipil dan lingkungan

\begin{tabular}{|c|c|c|c|c|}
\hline Penulis & Topik & $\begin{array}{c}\text { Sub } \\
\text { topik }\end{array}$ & $\begin{array}{l}\text { Objek/ } \\
\text { Lokasi }\end{array}$ & $\begin{array}{c}\text { Analisis } \\
\text { atau } \\
\text { metode }\end{array}$ \\
\hline $\begin{array}{l}\text { (Shams \& } \\
\text { Rahman, } \\
\text { 2010) }\end{array}$ & $\begin{array}{l}\text { Manajem } \\
\text { en } \\
\text { Bencana } \\
\text { dan SDA }\end{array}$ & $\begin{array}{l}\text { Analisis } \\
\text { resiko } \\
\text { terhadap } \\
\text { arsenic }\end{array}$ & $\begin{array}{l}\text { Air tanah } \\
\text { di distrik } \\
\text { Chapai } \\
\text { Nawabga } \\
\text { nj, } \\
\text { Banglade } \\
\text { sh }\end{array}$ & $\begin{array}{l}\text { multiple } \\
\text { ring } \\
\text { buffer } \\
\text { analysis }\end{array}$ \\
\hline $\begin{array}{l}\text { (Witten et } \\
\text { al., 2011) }\end{array}$ & $\begin{array}{l}\text { Urban } \\
\text { planning } \\
\text { dan } \\
\text { infrastruk } \\
\text { tur }\end{array}$ & $\begin{array}{l}\text { Fasilitas } \\
\text { sosial } \\
\text { /fasos dan } \\
\text { Fasum/fa } \\
\text { silitas } \\
\text { umum }\end{array}$ & $\begin{array}{l}\text { New } \\
\text { Zealand }\end{array}$ & $\begin{array}{l}\text { Buffer } \\
\text { analysis } \\
\text { dan } \\
\text { network } \\
\text { analysis }\end{array}$ \\
\hline
\end{tabular}




\begin{tabular}{|c|c|c|c|c|}
\hline Penulis & Topik & $\begin{array}{l}\text { Sub } \\
\text { topik }\end{array}$ & $\begin{array}{l}\text { Objek/ } \\
\text { Lokasi }\end{array}$ & $\begin{array}{c}\text { Analisis } \\
\text { atau } \\
\text { metode }\end{array}$ \\
\hline $\begin{array}{l}\text { (Karsauli } \\
\text { ya, 2013) }\end{array}$ & $\begin{array}{l}\text { Manajem } \\
\text { en } \\
\text { sampah } \\
\text { dan } \\
\text { manajem } \\
\text { en resiko }\end{array}$ & Sampah & $\begin{array}{l}\text { River } \\
\text { Yamuna, } \\
\text { India }\end{array}$ & $\begin{array}{l}\text { Multiple } \\
\text { ring } \\
\text { buffer } \\
\text { analysis }\end{array}$ \\
\hline $\begin{array}{l}\text { (Ridwan, } \\
\text { 2014) }\end{array}$ & $\begin{array}{l}\text { Transport } \\
\text { asi dan } \\
\text { urban } \\
\text { planning }\end{array}$ & $\begin{array}{l}\text { Transit } \\
\text { Oriented } \\
\text { Developm } \\
\text { ent /TOD }\end{array}$ & Makassar & $\begin{array}{l}\text { Genetika } \\
\text { alghoritm } \\
\text { a, } \\
\text { multiple } \\
\text { ring } \\
\text { buffer } \\
\text { analysis, } \\
\text { dan } \\
\text { network } \\
\text { analysis }\end{array}$ \\
\hline $\begin{array}{l}\text { (Mahami } \\
\text { d, 2016) }\end{array}$ & $\begin{array}{l}\text { Manajem } \\
\text { en } \\
\text { sampah } \\
\text { dan } \\
\text { manajem } \\
\text { en resiko }\end{array}$ & $\begin{array}{l}\text { TPA } \\
\text { /tempat } \\
\text { pembuan } \\
\text { gan akhir }\end{array}$ & $\begin{array}{l}\text { Ramallah } \\
\text { Palestina }\end{array}$ & $\begin{array}{l}\text { Multi- } \\
\text { criteria } \\
\text { analysis } \\
\text { dan } \\
\text { buffer } \\
\text { analysis }\end{array}$ \\
\hline $\begin{array}{l}\text { (Bilaşco } \\
\text { et al., } \\
\text { 2017) }\end{array}$ & $\begin{array}{l}\text { Transport } \\
\text { asi dan } \\
\text { manajem } \\
\text { en resiko }\end{array}$ & $\begin{array}{l}\text { Polusi } \\
\text { suara }\end{array}$ & $\begin{array}{l}\text { Kota } \\
\text { Cluj- } \\
\text { Napoca, } \\
\text { Rumania }\end{array}$ & $\begin{array}{l}\text { Multiple } \\
\text { ring } \\
\text { buffer } \\
\text { analysis }\end{array}$ \\
\hline $\begin{array}{l}\text { (Asif et } \\
\text { al., 2020) }\end{array}$ & $\begin{array}{l}\text { Manajem } \\
\text { en } \\
\text { sampah, } \\
\text { SDA dan } \\
\text { manajem } \\
\text { en resiko }\end{array}$ & $\begin{array}{l}\text { TPA } \\
\text { /tempat } \\
\text { pembuan } \\
\text { gan akhir }\end{array}$ & $\begin{array}{l}\text { Kota } \\
\text { Lahore, } \\
\text { Pakistan }\end{array}$ & $\begin{array}{l}\text { Multi- } \\
\text { criteria } \\
\text { decision } \\
\text { aid } \\
(M C D A) \\
\text { dan } \\
\text { multiple } \\
\text { ring } \\
\text { buffer } \\
\text { analysis }\end{array}$ \\
\hline $\begin{array}{l}\text { (Sahitya } \\
\text { \& Prasad, } \\
\text { 2020) }\end{array}$ & $\begin{array}{l}\text { Transport } \\
\text { asi dan } \\
\text { Urban } \\
\text { Planning }\end{array}$ & $\begin{array}{l}\text { Fasilitas } \\
\text { sosial }\end{array}$ & $\begin{array}{l}\text { Kota } \\
\text { Hyderaba } \\
\text { d, India }\end{array}$ & $\begin{array}{l}\text { multiple } \\
\text { ring } \\
\text { buffer } \\
\text { analysis }\end{array}$ \\
\hline
\end{tabular}

Pada tabel 1 memperlihatkan pengaplikasian buffer analysis/multiple ring buffer analysis dalam ilmu teknik sipil dan lingkungan sangat bervariatifdari metode hingga feature.Untuk feature terdapat point, line hingga polygon (lihat gambar 2 dan 3). Sementara untuk analisis, beberapa penelitian mengintegrasikan buffer analysis/multiple ring buffer analysis dengan analisis lainnya, seperti pada penelitian Ridwan, untuk menentukan lokasi TOD, penulis melakukan teknik overlay pada beberapa peta tematik (peta tata guna lahan, jaringan jalan, fasos, bus stop dan fungsi bangunan)(2014). Hal yang sama juga dilakukan oleh Asif dan kawankawan yang melakukan overlay peta untuk analisis awal lokasi TPA (2020) dan juga Witten dan kawan-kawan (2011).
Penerapan buffer analysis digunakan ketika yang menjadi dasar besaran area disekitar feature yang diinginkan hanya satu, seperti yang dilakukan oleh Witten dan kawan-kawan yang hanya menggunakan satu lapisan buffer, karena batasan penelitiannya hanya mencakup area cakupan pejalan kaki saja di sekitar fasilitas sosial yang ada di New Zealand (2011). Sementara yang menggunakan multiple ring buffer, dasar jarak terhadap feature lebih dari satu, seperti pada penentuan TOD, penulis menggunakan 2 jarak sebagai dasar, yaitu jarak pejalan kaki dan jarak pengguna sepeda (Ridwan, 2014), seperti yang terlihat pada gambar 4 .

Pada tabel 1 juga memperlihatkan selain teknik overlay, terdapat teknik analisis yang lebih dahulu terintegrasi sebelum pengaplikasian buffer analysis, yaitu teknik decision making. Teknik ini menjadi teknik awal yang dilakukan beberapa peneliti untuk menentukan lokasi-lokasi potensial pada penelitiannya, jika terdapat begitu banyak lokasi potensial, seperti penerapan MCDA/Multicriteria decision aid (Asif et al., 2020); multi-criteria analysis (Mahamid, 2016)hingga genetika algoritma (Ridwan, 2014). Hasil dari teknik decision making inilah yang nantinya akan dilakukan buffer analysis.

Penerapan buffer analysis digunakan ketika yang menjadi dasar besaran area disekitar feature yang diinginkan hanya satu, seperti yang dilakukan oleh Witten dan kawan-kawan yang hanya menggunakan satu lapisan buffer, karena batasan penelitiannya hanya mencakup area cakupan pejalan kaki saja di sekitar fasilitas sosial yang ada di New Zealand (2011). Sementara yang menggunakan multiple ring buffer, dasar jarak terhadap feature lebih dari satu, seperti pada penentuan TOD, penulis menggunakan 2 jarak sebagai dasar, yaitu jarak pejalan kaki dan jarak pengguna sepeda (Ridwan, 2014), seperti yang terlihat pada gambar 4 . 
Penerapan buffer analysis/multiple ring buffer analysis menjadikan satusatunya jarak sebagai variable penentu besaran area wilayah, sehingga untuk penelitian yang memiliki variable tambahan, seperti waktu ataupun elevasi, teknik analisis ini membutuhkan analisis tambahan untuk proses penyelesaiannya. Pada tabel di atas, dua penelitian menggunakan network analysis sebagia analisis akhirnya, seperti penelitian Witten dan kawan-kawan yang menggunakan network analysis untuk mendapatkan cakupan fasilitas terdekat dengan mempertimbangan variable jaringan jalan yang ada (2011), sama halnya dengan penelitian penentuan TOD yang menjadikan keberadaan jaringan jalan sebagai salah satu dasar penentuan, sehingga menerapakan network analysis sebagai analisis lanjutan dari multiple ring buffer analysis (Ridwan, 2014).

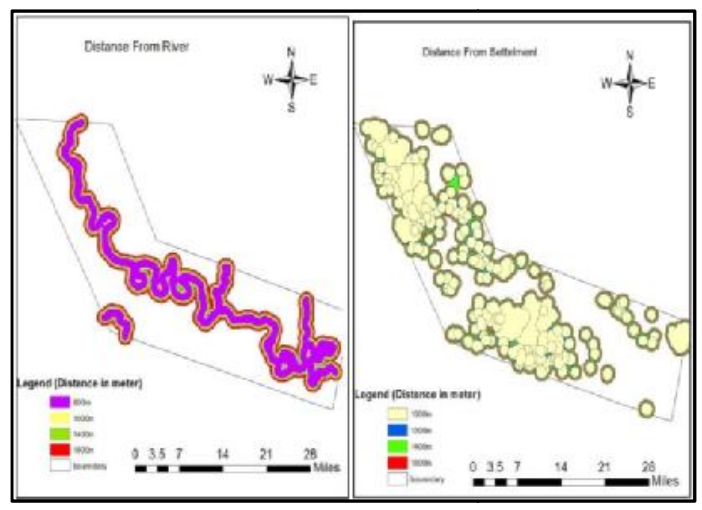

Gambar 2. Feature dengan line dan polygon ((Karsauliya, 2013)

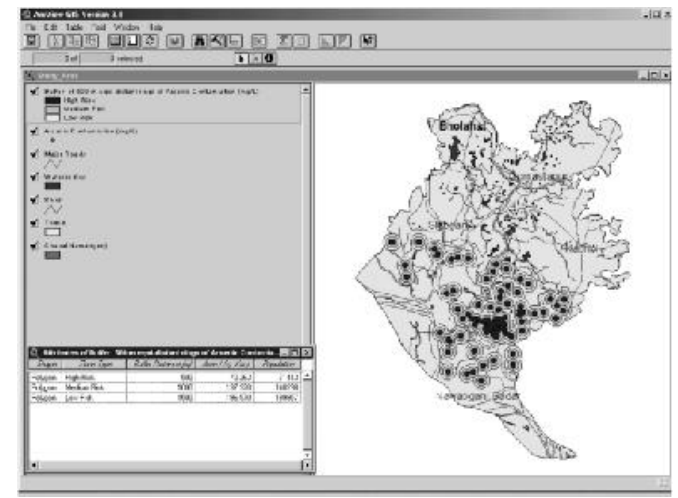

Gambar 3. Feature dengan point (Shams \& Rahman, 2010)

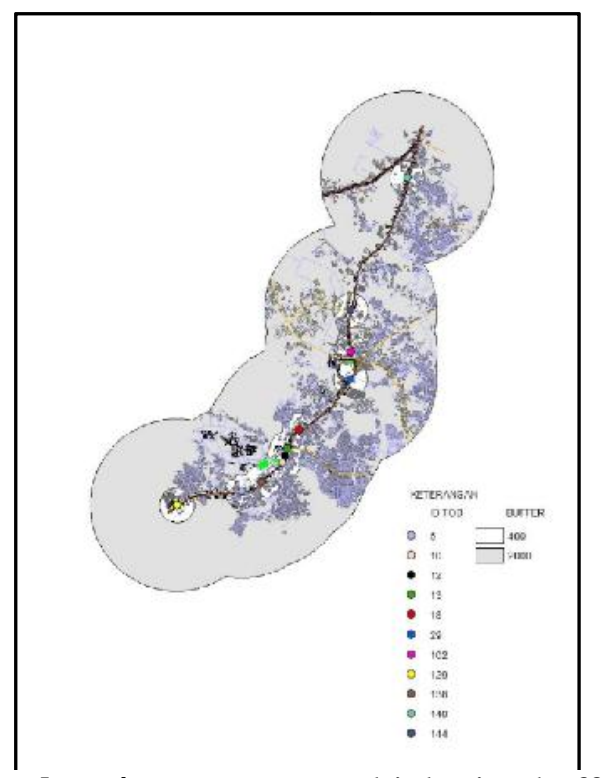

Gambar 4. Penerapan multiple ring buffer analysis(Ridwan, 2014)

\section{KESIMPULAN}

Tulisan ini memaparkan pengapliaksian buffer analysis/multiple ring buffer analysis dalam dunia teknik sipil dan lingkungan. Dari pemaparan di atas, secara umum gambar 5 menjelaskan pengaplikasian teknik analisis ini terbagi atas 2, yaitu untuk menentukan area pelayanan (service area), dan hal ini umumnya berhubungan dengan bidang teknik sipil. Yang kedua adalah untuk mengetahui area dampak (impact area), umumnya hal ini berhubungan dengan teknik lingkungan yang beririsan dengan teknik sipil.

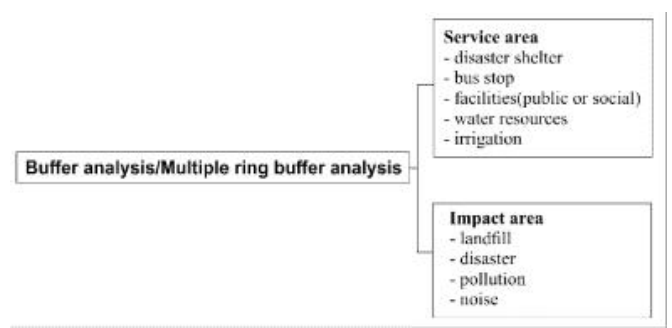

Gambar 1. Pengaplikasian buffer analysis/multiple ring buffer analysis dalam teknik sipil dan lingkungan 
Pengaplikasian buffer analysis digunakan jika hanya terdapat satu jarak yang dijadikan dasar, sementara jika lebih dari dua jarak yang dijadikan acuan, maka dapat menggunakan multiple ring buffer analysis.

Dalam tulisan ini juga ditemukan batasan penggunaan dari buffer analysis dan multiple ring buffer analysis. Karena konsep dari analisis ini adalah jarak yang menjadi satu-satunya acuan/varaibel, maka untuk penelitian yang mempertimbangakan variable lainnya, seperti waktu tempuh terdekat, elevasi, ataupun unsur penilaian yang berhubungan dengan jumlah atau banyaknya fasilitas/unsur lain, maka pengintegrasian analisis tambahan di akhir analisis adalah sebuah solusi. Sebagai contoh untuk menentukan area layanan sekolah berdasarkan buffer analysis, akan menjadi sangat tidak efektif, karena hanya menjadikan jarak cakupan (misalnya 1000 meter), sementara pada realitanya penempatan sekolah terkadang bukan berada di pusat pemukiman, dan juga dalam penentuan areal layanan sekolah, selain jarak tempuh yang menjadi pedoman, unsur pemukiman, dan keberadaan aksesbilitas juga menjadi variable penentu. Sehingga dibutuhkan analisis tambahan untuk mengakomodasi variable tambahan selain jarak, salah satunya yang dipaparkan dalam tulisan ini adalah network analysis.

\section{DAFTAR PUSTAKA}

Asif, K., Chaudhry, M. N., Ashraf, U., Ali, I., \& Ali, M. (2020). A GIS-based multi-criteria evaluation of landfill site selection in lahore, Pakistan. Polish Journal of Environmental Studies, 29(2), 1511-1521. https://doi.org/10.15244/pjoes/95181

Bilaşco, Ş., Govor, C., Roşca, S., Vescan, I., Filip, S., \& Fodorean, I. (2017). GIS model for identifying urban areas vulnerable to noise pollution: case study. Frontiers of Earth Science, 11(2), 214-228.
Esri. (2012). The Modern Platform for Civil IT. GIS Solution for Civil Engineering, 9688(9), 9688.

Retrieved from http://www.esri.com/library/brochures /pdfs/gis-sols-for-civilengineering.pdf

Karsauliya, S. (2013). Application of Remote Sensing and GIS in Solid Waste Management: A Case Study of Surroundings of River Yamuna, India. International Journal of Environmental Engineering and Management, 4(6), 2231-1319. Retrieved from http://www.ripublication.com/

Mahamid, I. (2016). Multi-criteria and landfill site selection using GIS : a case study from Palestine Multi Criteria and Landfill Site Selection Using Gis : A Case Study From Palestine. (January 2010).

Mitchell, A., \& Minami, M. (1999). The ESRI guide to GIS analysis: geographic patterns \& relationships (Vol. 1). ESRI, Inc.

Proximity analysis. (n.d.). Retrieved October 29, 2021, from https://desktop.arcgis.com/en/arcmap/ 10.3/analyze/commonly-usedtools/proximity-analysis.htm

Ridwan, V. F. (2014). Optimalisasi Konsep Penempatan Transit Oriented Development dengan Menggunakan Sistem Informasi Geografi dan Genetika Algoritma di Jalan Perintis Kemerdekaan Kota Makassar. Hasanuddin University.

Sahitya, K. S., \& Prasad, C. S. R. K. (2020). Evaluation of opportunity based urban road network accessibility using GIS. Spatial Information Research, 28(4), 487493. https://doi.org/10.1007/s41324019-00309-6

Shams, S., \& Rahman, S. M. S. (2010). GIS based Risk Analysis for Arsenic Contamination : A Case Study of Chapai Nawabganj District in Bangladesh. International Conference 
on Environmental Aspects of

Bangladesh (ICEAB10), 146-148.

Wang, X., \& vom Hofe, R. (2007).

Research Methods in Urban and

Regional Planning.

https://doi.org/10.1007/978-3-54049658-8

Witten, K., Pearce, J., \& Day, P. (2011).
Neighbourhood Destination

Accessibility Index: A GIS Tool for

Measuring Infrastructure Support for

Neighbourhood Physical Activity.

Environment and Planning A:

Economy and Space, 43(1), 205-223.

https://doi.org/10.1068/a43219 